\title{
FAKTOR-FAKTOR TERPERSEPSI YANG MEMENGARUHI PENGGUNAAN KARTU TOL ELEKTRONIK
}

\author{
Ratna Muljani Santosa \\ Manajemen, Universitas Bunda Mulia \\ Alamat surel: santosaratna@yahoo.com \\ Michael Christian \\ Manajemen, Universitas Bunda Mulia \\ Alamat surel: michaelchristianid@gmail.com
}

\begin{abstract}
October 2017 is the starting point of non-cash payment through the Electronic Toll Card simultaneously in Indonesia. The use of payments on toll roads with this system is believed to reach the target 100\%. This is not a new thing since the Non-Cash National Movement program has been initiated in 2014. However, as a country that is enjoying the development of information technology in the digital things, the role of payment method in the toll road with this system still needs to be studied not only in terms of benefits which can be provided to the community, but also to the impact of ease of use on each toll roads in Indonesia. This study aims to explain the influence of perceived factors for the users that is the useful and ease of use its payment method. Using SPSS 22.0, this study explains that the use of Electronic Toll Cards is influenced by the factor of useful and ease of use. This study used 73 respondents as an Electronic Toll Card user. Suggestion for further researchesis able to focus more on high-frequency toll roads. It aims to explain the consistency of the factor "useful" and ease of use for users. In addition, the socialization the way of use is considered important to be encouraged by the government in the succession of the NonCash National Movement.
\end{abstract}

Keywords: card, electronic, toll, useful, ease

\begin{abstract}
Abstrak
Bulan Oktober 2017 merupakan titik awal diberlakukannya pembayaran non tunai melalui Kartu Tol Elektronik secara serentak di Indonesia. Tidak tangung-tanggung penggunaan pembayaran di jalan tol dengan sistem ini dipercaya mencapai target $100 \%$ terimplementasi. Hal ini sebenarnya bukan hal baru mengingat program Gerakan Nasional Non Tunai sudah dicetuskan sejak tahun 2014. Namun demikian, sebagai negara yang sedang menikmati perkembangan teknologi informasi ke arah digital, peranan metode pembayaran di ruas tol dengan kartu ini masih perlu dikaji tidak hanya dari segi manfaat yang dapat diberikan kepada masyarakat, namun juga pada dampak kemudahan penggunannya pada tiap ruas tol. Penelitian ini bertujuan untuk menjelaskan pengaruh faktor terpersepsi bagi masyarakat yaitu manfaat dan kemudahan penggunaan terhadap penggunaan metode pembayaran tersebut. Dengan menggunakan SPSS 22.0, penelitian ini menjelaskan bahwa penggunaan Kartu Tol Elektronik dipengaruhi oleh faktor manfaat dan kemudahan dalam penggunaan. Penelitian ini menggunakan 73 responden sebagai pengguna Kartu Tol Elektronik. Saran bagai penelitian selanjutnya adalah dapat lebih fokus dalam ruas gardu tol otomatis pada titik-titik dengan frekuensi tinggi. Hal ini bertujuan untuk menjelaskan konsistensi faktor manfaat dan kemudahan penggunaan bagi para pengguna. Selain itu, sosialisasi cara penggunaan dirasa penting untuk digalakkan pemerinta dalam suksesi Gerakan Nasional Non Tunai.
\end{abstract}

Kata kunci: kartu, elektronik, tol, manfaat, kemudahan

\section{PENDAHULUAN}

\section{Latar Belakang}

Wacana mengenai penggunaan pembayaran di jalan tol dengan sistem non tunai sepertinya dalam waktu dekat akan diberlakukan bahkan dengan capaian target 100\% (Sawitri, 2017). Target ini merupakan implementasi dukungan terhadap program pemerintah yang dikenal dengan Gerakan Nasional Non Tunai (Fauzi, 2017) yang dicetuskan pada tahun 2014. Berjalannya waktu, gerakan yang dikenal dengan GNNT tesebut telah memberikan dampak yang siginifikan dalam menggeser pola pembayaran pada gardu tol di Indonesia. 
Tahun 2015, Jasa Marga mencatat bahwa penggunaan kartu tol elektronik (KTE) sebesar $15,32 \%$ dari seluruh transaksi pembayaran di gardu tol (Dirgantoro, 2016). Angka tersebut menjelaskan bahwa masih tingginya sistem pembayaran lainnya yang dilakukan pengguna jalan tol. Namun demikian berbagai upaya dilakukan pemerintah yang menggandeng badan usaha pengelola jalan tol. Dalam bulan Juli 2017, capaian angka penggunan KTE di Indonesia mencapai angka 30\% (Simorangkir, 2017). Melihat angka tersebut memang masih cukup jauh dalam capaian $100 \%$ di tahun ini. Namun paling tidak, angka tersebut menjelaskan bahwa pola pembayaran konvensional oleh pengguna jalan tol sebenarnya dapat digeser ke pola pembayaran yang lebih efisien yaitu non tunai.

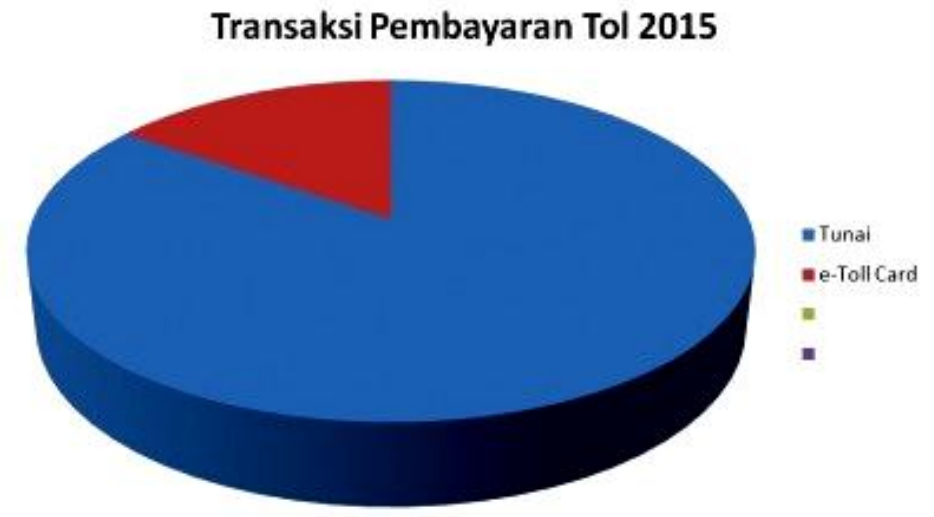

Sumber: Dirgantoro (2016)

Gambar 1. Transaksi Pembayaran Tol Tahun 2015

GNTT dalam bentuk pembayaran dengan KTE juga tidak hanya dilihat sebagai upaya pemerintah dalam mengurangi angka kemacetan yang ada. Pembayaran dengan KTE juga setidaknya dalam mengurangi antrian yang tidak jarang ditemukan pada ruas tol di Indonesia. KTE yang dapat berfungsi sebagai alat pengganti uang tunai (detikFinance, 2012) juga memberikan manfaat kemudahan dari efisiensi durasi waktu dalam melakukan transaksi pembayaran di pintu gardu tol. Pemotongan durasi waktu dengan menggunakan KTE bisa sampai 3-4 detik, jauh lebih cepat dari transaksi dengan pembayaran konvensional yang bisa menghabiskan 20 detik (Ariyanti, 2016). Manfaat lainnya dapat dilihat dari kemudahan dalam menggunakan kartu seperti KTE yang dikeluarkan oleh Bank Mandiri yang tidak memiliki masa kadaluarsa kartu (detikFinance, 2012). Namun demikian, upaya tersebut masih terkendala dengan koordinasi penerapan pembayaran non tunai pada ruas tol yang dimiliki oleh perusahaan swasta (Deny, 2016).

Secara fungsional, KTE juga dapat dimungkinkan untuk digunakan dalam melakukan transaksi di luar gardu tol seperti di Stasiun Pengisian Bahan Bakar Umum (SPBU), toko ritel, dan beberapa toko makanan dan minuman (satulayanan.id, 2014). Rasa panik dalam mempersiapkan uang kecil atau mengabaikan jumlah uang kembalian pembayaran di gardu tol (Murdaningsih, 2016) merupakan hal-hal yang sering terjadi kepada para pengguna jalan tol. Belum lagi ditambah dengan kemudahan dalam melaklukan pengisian ulang saldo pada KTE seperti yang dikeluarkan Mandiri-Indomaret yang dapat diisi ulang di 20.000 titik seperti Anjungan Tunai mandiri (ATM), kantor cabang sampai outlet.

Di tengah target pemerintah dalam menggeser pola pembayaran konvensional pengguna jalan tol menjadi pembayaran dengan sistem non tunai, strategi pendorong terus dilakukan seperti memberikan 
potongan harga tarif tol sebesar $20 \%$ dengan menggunakan KTE (Hasyim \& Priyanto, 2017). Namun demikian 2017 hanya menyisakan waktu kurang dari satu semester lagi dimana sasaran capaian 100\% sudah harus terealisasi. Bulan Oktober 2017 akan menjadi titik awal serentak dimana pemberlakuan pembayaran tarif tol harus menggunakan non tunai. Persepsi masyarakat mengenai apakah manfaat yang akan diperoleh akan dapat berbanding lurus dengan kemudahan penggunaannya masih perlu dikaji lagi. Hal ini didasarkan pada kompleksitas pihak yang terlibat dari implementasi sistem pembayaran ini yaitu pengembang ruas jalan tol, pihak pencetak KTE dan pihak Bank sebagai otorisasi pembayaran dalam KTE. Oleh karena itu, penelitian ini bertujuan untuk menjelaskan faktor-faktor terpersepsi pengguna dan pengaruhnya terhadap penggunan KTE.

\section{Masalah Penelitian}

Masalah dalam penelitian ini adalah sebagai berikut:

1. Apakah faktor kemudahan terpersepsi secara parsial berpengaruh terhadap penggunaan kartu tol elektronik?

2. Apakah faktor manfaat terpersepsi secara parsial berpengaruh terhadap penggunaan kartu tol eletronik?

3. Apakah faktor kemudahan terpersepsi dan manfaat terpersepsi secara simultan berpengaruh terhadap penggunaan kartu tol elektronik?

\section{Tujuan Penelitian}

Tujuan penelitian ini adalah untuk:

1. Mengetahui dan menjelaskan apakah terdapat pengaruh faktor kemudahan terpersepsi secara parsial terhadap penggunaan kartu tol elektronik.

2. Mengetahui dan menjelaskan apakah terdapat pengaruh faktor manfaat terpersepsi secara parsial.
3. Mengetahui dan menjelaskan apakah terdapat pengaruh faktor kemudahan terpersepsi dan manfaat terpersepsi secara simultan terhadap penggunaan kartu tol elektronik.

\section{TINJAUAN PUSTAKA}

\section{Sistem Pembayaran Non Tunai}

Perkembangan teknologi informasi nyatanya memberikan perubahan pada keseharian masyarakat, salah satunya metode pembayaran dalam bertransaksi. Hingga saat ini setidaknya masih terdapat dua jenis metode pembayaran yaitu tunai dan non tunai. Di Indonesia penggunaan metode pembayaran dengan non tunai sepertinya dapat dikatakan dimulai dengan adanya kartu debit atau yang biasa disebut dengan kartu ATM yang dikeluarkan oleh berbagai bank. Secara umum, pembayaran dengan metode non tunai memiliki kelebihan seperti dalam ketersediaannya penyedia layanan tidak lagi bergantung pada bank sebagai salah satu lembaga keuangan yang resmi (Padashetty \& Kishore, 2013) dan juga metode ini dapat menghemat waktu tunggu antrian dan keluar dari titik gerai tertentu (Padashetty \& Kishore, 2013).

Namun demikian, pembayaran non tunai yang memiliki karakter dapat dibawa kemana saja ini nyatanya masih belum populer digunakan, namun diprediksi menjadi bentuk aplikasi yang potensial digunakan secara massal (Padashetty \& Kishore, 2013). Padahal bila dilihat dari teknologi yang digunakan, pembayaran non tunai seperti KTE sudah memiiki teknologi yang disebut dengan Radio Frequency Identification (RFID) ini sudah populer dalam industri jasa belakangan ini (Ozturk, 2016). Lebih lanjut dijelaskan bahwa teknologi RFID tersebut sistem pembayaran non tunai di satu sisi memiliki risiko, seperti cenderung memiliki ketidakpastian fungsi dalam penggunaan. Hal ini disebabkan karena pengguna diharuskan mengetahui cara penggunaan sistem tersebut. Hal ini memberikan kekuatiran bagi pengguna.

Metode pembayaran dengan non tunai khususnya yang bersifat mudah dibawa 
kemana saja. Secara sistem dapat didefinisikan sebagai suatu sistem yang menggunakan gawai untuk melakukan transaksi seperti melakukan pembayaran pada tagihan dan transaksi perbankan (Padashetty \& Kishore, 2013). Padashetty \& Kishore (2013) menjelaskan bahwa faktor penggunaan dalam pembayaran secara mobile dapat diartikan sebagai satu bagian proses sistemik yang dapat meningkatkan kinerja pengguna. Hal ini menjelaskan bahwa penggunaan sistem pembayaran ini dapat memberikan manfaat dan juga kemudahan penggunaan dalam melakukan transaksi pembayaran.

\section{Keterkaitan Antar Peubah}

Pada bagian sebelumnya telah dijelaskan bahwa sistem pembayaran mobile yang berbentuk non tunai memberikan manfaat dan juga kemudahan dalam penggunaan. Manfaat kemudahaan ini diharapkan dapat mendukung efektivitas dan efisiensi transaksi pembayaran yang harus dilakukan oleh pengguna (Kim , Mirsobit , \& Lee, 2010). Pertimbangan dalam menggunakan metode pembayaran secara mobile adalah faktor penghematan waktu yang diperoleh setiap melakukan transaksi dan juga faktor dapat dibawa dengan mudah. Namun demikian, perkembangan teknologi pada sistem pembayaran non tunai selain memberikan manfaat juga diikuti dengan risiko, salah satunya masih terdapatnya ketidakpastian (Ferrer, Dew, \& Apte , 2010) sebagai alat pembayaran untuk cakupan yang lebih banyak. Kemudahan dalam menggunakan metode pembayaran non tunai memberikan pengaruh yang signifikan terhadap keinginan masyarakat dalam menggunakan sistem pembayaran tersebut (Cheng, 2013).

\section{Penelitian Sebelumnya Mengenai Pembayaran Non Tunai Pada Sektor Jasa} Penelitian yang dilakukan oleh Padashetty \& Kishore (2013) di Banglore India menjelaskan bahwa faktor terpersepsi dari masyarakat mengenai penggunaan, kepercayaan dan kemudahan penggunaan tidak memberikan pengaruh pada pembayaran secara mobile. Dalam penelitian ini juga dijelaskan juga bahwa penggunaan gawai sebagai pembayaran non tunai yang bersifat mobile dapat digunakan di negara dalam mendukung aktivitas perbankan secara daring, membangun karir melalui serapan informasi yang cepat, pembayaran berbasis daring, sampai kepada dompet elektronik. Ozturk (2016) melalui penelitian yang dilakukan di USA pada sektor hospitaliti menjelaskan bahwa kemudahan penggunaan transaksi pembayaran non tunai memengaruhi faktor manfaat yang dibentuk oleh pembayaran non tunai, dan faktor manfaat yang terbentuk tersebut membentuk pengaruh pada keputusan menggunakan metode transaksi pembayaran non tunai.

\section{METODE}

\section{Hipotesis dan Model Penelitian}

Hipotesis yang digunakan dalam penelitian ini adalah sebagai berikut:

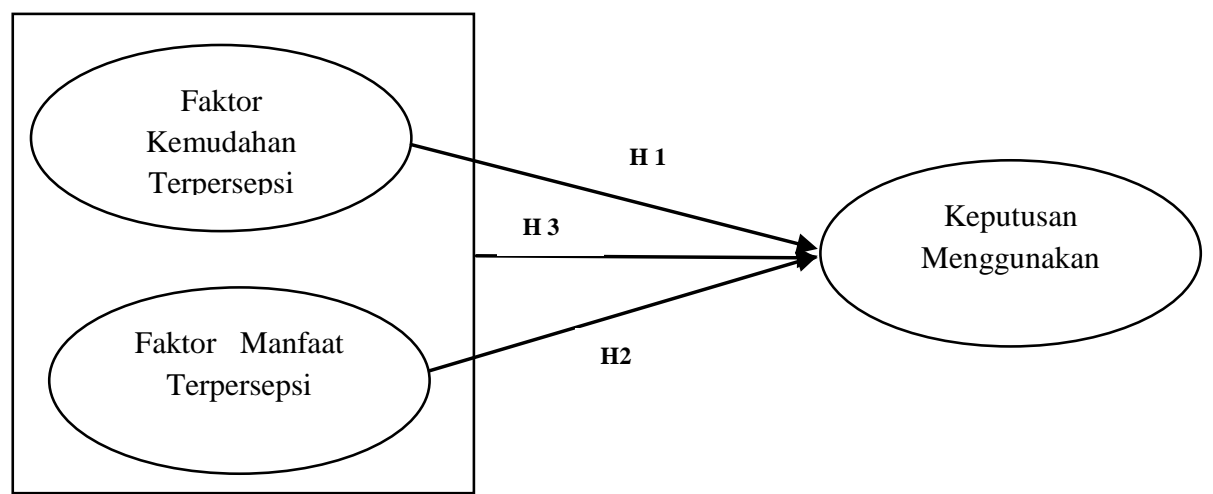

Sumber: Padashetty \& Kishore (2013) ; Ozturk (2016)

Gambar 2. Hipotesis dan Model Penelitian 


\section{Metode Penelitian}

Karakter populasi dalam penelitian ini adalah seluruh pengguna KTE di Jabodetabek dengan jumlah sampel yang diperoleh sebesar 73 orang. Jumlah ini didasarkan pada jumlah indikator dikali dengan 5-10. Penelitian ini memiliki 8 indikator yang kemudian diolah secara kuantitatif dengan menggunakan Statistical Package for Social Science (SPSS) 22.0. Model regresi dalam model penelitian ini kemudian digunakan untuk melakukan ujiuji yang dibutuhkan yaitu uji kesahihan dan kehandalan, uji asumsi klasik, koefisien determinasi, uji signifikansi dan simultan. Beberapa analisis statistik deskriptif juga disajikan untuk menjelaskan hasil penelitian ini.

\section{Operasionalisasi Konstruk}

Instrumen yang digunakan dalam penelitian ini adalah sebagai berikut:

Tabel 1. Instrumen Penelitian

\begin{tabular}{|c|c|c|}
\hline Peubah & Indikator & Skala Pengukuran \\
\hline \multirow{2}{*}{$\begin{array}{l}\text { Faktor Kemudahan } \\
\text { Terpersepsi }\end{array}$} & Kemudahan dalam penggunaan & \multirow{8}{*}{ Likert $1 \mathrm{~s} / \mathrm{d} 5$} \\
\hline & Pemahaman dalam penggunaan & \\
\hline \multirow{3}{*}{ Faktor Manfaat Terpersepsi } & Memberikan kemudahan & \\
\hline & Menghemat waktu & \\
\hline & Meningkatkan efektivitas & \\
\hline \multirow{3}{*}{ Keputusan Menggunakan } & Menggunakan karena kondisi & \\
\hline & Tingkat keharusan menggunakan & \\
\hline & Berencana menggunakan lagi & \\
\hline
\end{tabular}

Sumber: Padashetty \& Kishore (2013), Ozturk (2016)

\section{HASIL DAN PEMBAHASAN}

\section{Deskripsi Karakter Responden}

Penelitian ini memiliki responden laki-laki sebanyak 37 orang dan perempuan 36 orang. Berdasarkan hasil ini dapat dijelaskan bahwa dari seluruh kuesioner yang disebarkan, pengembalian kuesioner yang layak untuk diolah berasal dari responden laki-laki $50,7 \%$ dan sisanya sebanyak 49,3\% berasal dari responden perempuan. Hal ini juga dapat menjelaskan bahwa fungsi KTE dalam penelitian dapat dirasakan oleh masyarakat baik laki-laki mau pun perempuan. Berdasarkan usia, responden yang terlibat didominasi oleh pengguna KTE dari kelompok usia 41-50 tahun yaitu sebanyak 24 orang $(32,9 \%)$ sedangkan responden yang paling sedikit berasal dari kelompok usia di atas 50 tahun. Hal ini dapat menjelaskan bahwa tuntutan mobilitas keseharian dalam menggunakan jasa jalan tol pada dua kelompok usia pertama dalam penelitian ini mencapai $42,4 \%$.

Tabel 2. Profil Responden ( $n=73)$

\begin{tabular}{lll}
\hline Deskripsi & Jumlah & \% \\
\hline Laki-laki & 37 & 50,7 \\
\hline Perempuan & 36 & 49,3 \\
\hline Usia & & \\
- 18-30 tahun & 19 & 26,0 \\
- 31-40 tahun & 12 & 16,4 \\
- 41-50 tahun & 24 & 32,9 \\
$\quad$ - Di atas 50 tahun & 18 & 24,7 \\
\hline
\end{tabular}

Sumber: Data primer 


\section{Statistik Deskripitif}

Berdasarkan

tabel

statistik

deksriptif, penelitian ini dapat menjelaskan bahwa angka penilaian terkecil dari responden adalah 1 dan 5 sebagai angka terbesar, sehingga angka ukur dari dispersi data dalam penelitian ini sebesar 4. Angka rata-rata dari loloh-balik terkecil 3,82 sampai dengan 4,00 untuk seluruh butir yang digunakan dalam penelitian ini. Hasil tabel tersebut juga dapat menjelaskan bahwa sebaran data terhadap rata-rata angka lolohbalik berada pada angka 0,935 hingga 1,236, sedangkan sebaran rata-rata sampel terhadap rata-rata keseluruhan sampel berada pada angka 0,109 hingga 0,145 .

Tabel 3. Statistik Deskriptif $(n=73)$

\begin{tabular}{llllll}
\hline Item & Range & Min & Max & Std. Error (of mean) & Std. Deviation \\
\hline KP1 & 4 & 1 & 5 & 0,145 & 1,236 \\
\hline KP2 & 4 & 1 & 5 & 0,128 & 1,092 \\
\hline KP3 & 4 & 1 & 5 & 0,129 & 1,106 \\
\hline MP1 & 4 & 1 & 5 & 0,122 & 1,045 \\
\hline MP2 & 4 & 1 & 5 & 0,109 & 0,935 \\
\hline MP3 & 4 & 1 & 5 & 0,112 & 0,957 \\
\hline MP4 & 4 & 1 & 5 & 0,111 & 0,945 \\
\hline KM1 & 4 & 1 & 5 & 0,126 & 1,080 \\
\hline KM2 & 4 & 1 & 5 & 0,131 & 1,118 \\
\hline KM3 & 4 & 1 & 5 & 0,122 & 1,045
\end{tabular}

Sumber: Hasil Pengolahan SPSS 22.0

Dalam penelitian ini ada 1 butir yang harus dikeluarkan karena menunjukkan angka corrected item-total correlation di bawah 0,23 (tabel r).Di luar butir tersebut, penelitian ini memperlihatkan bahwa seluruh konstruk dinyatakan sahih (dapat digunakan). Pada tabel statistik kehandalan, koefisien Alpha Cronbach sebesar 0,914 (lebih besar dari 0,6) menunjukkan bahwa alat ukur yang digunakan dalam penelitian memiliki keajegan dan dapat dinyatakan andal.

Tabel 4. Uji Kesahihan $(n=73)$

\begin{tabular}{lr}
\hline Item & Corrected-item correlation \\
\hline KP1 & 0,689 \\
\hline KP2 & 0,873 \\
\hline KP3 & 0,870 \\
\hline MP1 & 0,858 \\
\hline MP2 & 0,798 \\
\hline MP3 & 0,791 \\
\hline MP4 & 0,782 \\
\hline KM1 & 0,850 \\
\hline KM2 & 0,786 \\
\hline KM3 & 0,760 \\
\hline
\end{tabular}

Sumber: Hasil Pengolahan SPSS 22.0

Tabel 5. Uji Keandalan ( $n=73)$

\begin{tabular}{ll}
\hline Cronbach's Alpha & Nof items \\
\hline 0,947 & 10 \\
\hline
\end{tabular}

Sumber: Hasil Pengolahan SPSS 22.0 


\section{Uji Normalitas}

Pengujian normalitas dengan P-P Plot menunjukkan bahwa titik-titik berada dan mengikuti sepanjang garis diagonal. Hal ini menunjukkan bahwa analisis regresi layak digunakan.

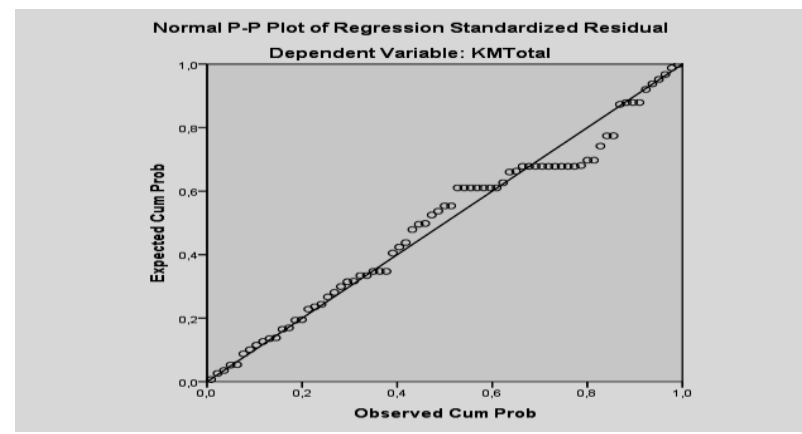

Sumber: Hasil Pengolahan SPSS 22.0

Gambar 3. Uji Normalitas

\section{Uji Multikolinieritas}

Tabel koefisien menunjukkan angka tolerance masing-masing peubah sebesar 0,358 atau lebih besar dari 0,1 . Hal ini memperlihatkan bahwa tidak terjadi gejala multikolinieritas. Angka pada Variance

Tabel 6. Uji Normalitas $(n=73)$

\begin{tabular}{lll}
\hline Model & Tolerance & VIF \\
\hline KP & 0,358 & 2,979 \\
\hline MP & 0,358 & 2,979 \\
\hline
\end{tabular}

Sumber: Hasil Pengolahan SPSS 22.0

\section{Uji Heteroskedastisitas}

Kesamaan atau ketidaksamaan variance dari residual satu pengamatan ke pengamatan yang lain dapat menjelaskan terjadinya heteroskedastisitas atau homoskedastisitas. Apabila variance dari residual pengamatan tetap maka

Tabel 7. Uji Heteroskedastisitas $(n=73)$

\begin{tabular}{ll} 
Model & Sig \\
\hline KP & 0,542 \\
\hline MP & 0,182
\end{tabular}

Sumber: Hasil Pengolahan SPSS 22.0

\section{Kesesuaian Model}

Berdasarkan hasil yang diperoleh dapat dikemukakan bahwa pengaruh menggunakan KTE dapat dijelaskan oleh faktor manfaat terpersepsi dan kemudahan
Inflation Factor (VIF) menunjukkan angka 0,979 untuk masing-masing peubah atau kurang dari 10. Hal ini juga semakin menguatkan penjelasan sebelumnya bahwa dalam penelitian ini tidak terjadi gejala multikolinieritas.

homoskedastitas. Nilai sig yang dihasilkan pada penelitian ini menunjukkan angka 0,542 (KP) dan 0,182 (KM). Hasil ini memperlihatkan bahwa angka tersebut lebih besar dari 0,05 sehingga dapat dikatakan bahwa tidak terjadi gejala heteroskedastisitas. terpersepsi sebesar 59,8\%. Hal ini juga menjelaskan bahwa masih ada faktor-faktor lain yang memiliki pengaruh terhadap keputusan menggunakan KTE. 
Tabel 8. Koefisien Determinasi $(\mathbf{n}=73)$

\begin{tabular}{llll}
\hline Model & $\boldsymbol{R}$ & $\boldsymbol{R}$ Square & Adjusted $\boldsymbol{R}$ Square \\
\hline 1 & 0,774 & 0,598 & 0,587 \\
\hline
\end{tabular}

Sumber: Hasil Pengolahan SPSS 22.0

Penelitian ini juga menjelaskan bahwa dari tabel yang ada, persamaan regresi dapat

dibentuk sebagai berikut: $\mathbf{Y}=\mathbf{0 , 8 5 8}+$ $0,279 \times 1+0,453 \times 2+e$.

Tabel 9. Regresi Berganda ( $n=73)$

\begin{tabular}{ll} 
Model & B \\
\hline (Constant) & 0,858 \\
\hline KP & 0,279 \\
\hline MP & 0,453 \\
\hline
\end{tabular}

Sumber: Hasil Pengolahan SPSS 22.0

\section{Uji Hipotesis}

Berdasarkan olahan data masingmasing peubah menunjukkan angka positif $(0,279$ dan 0,453$)$. Hasil ini menjelaskan bahwa Penggunaan KTE dipengaruhi positif oleh Faktor Manfaat Terpersepsi dan Penggunaan KTE dipengaruhi positif oleh Faktor Kemudahan Terpersepsi. Kemudian pada tabel juga menunjukkan angka $t$ hitung sebesar 2,298 dan 4,107 atau lebih besar 0,05 . Angka ini menjelaskan bahwa Penggunaan KTE dipengaruhi signifikan oleh Faktor Manfaat Terpersepsi dan Penggunaan KTE dipengaruhi signifikan oleh Faktor Kemudahan Penggunaan Terpersepsi.

Oleh karena itu dapat dijelaskan lagi bahwa Penggunaan KTE dipengaruhi Faktor Manfaat Terpersepsi dan Penggunaan KTE dipengaruhi positif oleh Faktor Kemudahan Penggunaan Terpersepsi secara

parsial. Hal ini sesuai dengan Hipotesis 1 dan Hipotesis 2 dimana peubah gayut dipengaruhi oleh masing-masing peubah bebas. Hasil ini sesuai dengan penelitian sebelumnya yang dilakukan oleh Padashetty \& Kishore (2013) dan Ozturk (2016) yang juga menjelaskan hasil kedua peubah tersebut memiliki pengaruh terhadap penggunaan sistem pembayaran secara mobile. Uji signifikansi berdasarkan tabel ANOVA dalam penelitian ini dijelaskan bahwa titik kesalahan yang terjadi jika nilai F hitung sebesar 52,133 sebesar 0.000 dimana nilai ini lebih kecil dari 0,05 . Hal ini juga menjelaskan bahwa peubah bebas secara bersama (faktor manfaat terpersepsi dan faktor kemudahan penggunaan terpersepsi) mampu menjelaskan perubahan pada peubah gayut (keputusan menggunakan) atau dengan kata lain model dinyatakan fit.

Tabel 10. Uji Parsial $(n=73)$

\begin{tabular}{ll}
\hline Model & $\mathbf{t}$ \\
\hline KP & 2,298 \\
\hline MP & 4,107
\end{tabular}

Sumber: Hasil Pengolahan SPSS 22.0

Tabel 11. Uji Simultan (n=73)

\begin{tabular}{lll}
\hline Model & $\boldsymbol{F}$ & Sig. \\
\hline Regression & 52,133 & 0,000 \\
\hline Sumber: Hasil Pengolahan SPSS 22.0
\end{tabular}




\section{SIMPULAN dan SARAN}

\section{Simpulan}

Berdasarkan hasil dan pembahasan di atas, maka simpulan penelitian ini adalah sebagai berikut:

1. Penggunaan KTE dipengaruhi oleh Faktor Manfaat Terpersepsi

2. Penggunaan KTE dipengaruhi oleh Faktor Kemudahan PenggunaanTerpersepsi

3. Penggunaan KTE dipengaruhi oleh Faktor Manfaat Terpersepsi dan Penggunaan KTE dipengaruhi positif oleh Faktor Kemudahan Penggunaan Terpersepsi secara bersamasama.

\section{Saran}

Saran untuk penelitian ini adalah pada indikator yang terkait dengan pemahaman penggunaan KTE. Faktor manfaat dari diberlakukan KTE sebaiknya harus diikuti dengan pemahaman pengguna KTE. Hal ini berguna untuk menyukseskan program GNNT menjadi tepat sasaran yaitu efisiensi waktu transaksi yang memudahkan pengguna. Dalam kaitannya dengan KTE, efisiensi berarti konsistensi durasi waktu yang dibutuhkan untuk melakukan transaksi pembayaran pada tiap gardu tol. Oleh karena itu, sebagai saran bagi pemerintah, pengembang ruas jalan tol dan penerbit KTE lebih maksimal melakukan sosialisasi mengenai cara menggunakan KTE. Sampai saat ini yang masih ditemukan adalah mengenai jadwal serentak diberlakukannya KTE, namun kurang diikuti dengan tata cara penggunaanya. Media-media iklan seperti billboard pada ruas jalan raya menjadi titik vital dalam sosialiasi tersebut. Disamping itu juga strategi sosialisasi dengan media elektronik seperti televisi dan radio masih dirasa perlu untuk digunakan.

\section{DAFTAR PUSTAKA}

Ariyanti, F. 2016. Desember Kamis, http://bisnis.liputan6.com. Retrieved September Selasa, 2017, from http://bisnis.liputan6.com: http://bisnis.liputan6.com/read/2685 594/seluruh-gerbang-tol-harusgunakan-e-toll-card-di-2017

Cheng, K. M. 2013. An Evaluation of RFID Door Security System at Taipei Arena Ice Lan Based on Technology Acceptance Model. International Journal of Management and Information Systems, 17 (2), 117129.

Deny, S. 2016. Maret Senin, http://bisnis.liputan6.com. Retrieved September Rabu , 2017, from http://bisnis.liputan6.com: http://bisnis.liputan6.com/read/2464 043/ini-kendala-penerapan-epayment-di-tol

DetikFinance. 2012. Januari Selasa, http://finance.detik.com. Retrieved September Selasa, 2017, from http://finance.detik.com: http://finance.detik.com/beritaekonomi-bisnis/d-1818204/iniuntung-rugi-pakai-e-toll-card

Dirgantoro, D. P. 2016. Januari Kamis, http://otodriver.com. Retrieved September Selasa, 2017, from http://otodriver.com:

http://otodriver.com/article/view/ber apa-persen-pengguna-e-toll-card-di2015/ut2SoOPgDLis0as_OeRILkwFWCgMZSgchh HFgZCazY 
Fauzi, Y. 2017. Maret Rabu, https://www.cnnindonesia.com.

Retrieved September Selasa, 2017, from

https://www.cnnindonesia.com:

https://www.cnnindonesia.com/ekon omi/20170315171447-92-

200379/dorong-gerakan-non-tunaijasa-marga-genjot-pembayaran-etoll/

Ferrer, G., Dew, N., \& Apte , U. 2010. When is RFID Right For Your Service? International Journal of Production Economics, 124(2), 414425.

Hasyim , I., \& Priyanto , W. 2017. Juni Selasa, https://bisnis.tempo.co. Retrieved September 2017, 2017, from https://bisnis.tempo.co: https://bisnis.tempo.co/read/news/20 17/06/13/090883957/mudik-lebaran2017-pengguna-e-toll-dapat-diskon20-persen

Kim , C., Mirsobit , M., \& Lee, I. 2010. An Empirical Examination of Factors Influencing The Intention to Use Mobile Payment. Computers in Human Behavior, 26, 310-322.

Murdaningsih, D. 2016. April Jumat, http://www.republika.co.id.

Retrieved September Selasa, 2017, from http://www.republika.co.id: http://www.republika.co.id/berita/ek onomi/korporasi/16/04/22/o5zlya36 8-enggak-pakai-ribet-bayar-tollebih-praktis-pakai-kartu-flazz
Ozturk, A. B. 2016. Customer acceptance of cashless payment systems in the hospitality industry. International Journal of Contemporary Hospitality Management, 28(4), 801-817.

Padashetty, S., \& Kishore, K. 2013. An Empirical Study On Consumer Adoption Of Mobile Payments In Bangalore City - A Case Study. Journal of Arts, Science \& Commerce, IV(1(1)), 83-94.

Petriella, Y. 2017. Januari Senin, http://industri.bisnis.com. Retrieved September Selasa, 2017, from http://industri.bisnis.com: http://industri.bisnis.com/read/20170 130/98/624222/penggunaan-e-tollmakin-penting

Satulayanan.id. 2014. November Kamis, http://satulayanan.id. Retrieved September Selasa , 2017, from http://satulayanan.id: http://satulayanan.id/layanan/index/ 38/e-toll/bank-mandiri

Sawitri , A. A. 2017. Agustus Selasa, https://bisnis.tempo.co/. Retrieved September Selasa, 2017, from https://bisnis.tempo.co/: https://bisnis.tempo.co/read/news/20 17/08/15/090900138/aturan-sistemnontunai-100-persen-di-tol-terbitbulan-ini

Simorangkir, E. 2017. September Selasa, https://finance.detik.com. Retrieved September Selasa, 2017, from https://finance.detik.com: https://finance.detik.com/beritaekonomi-bisnis/d-3629905/baru-30pengguna-tol-yang-pakai-uangelektronik 